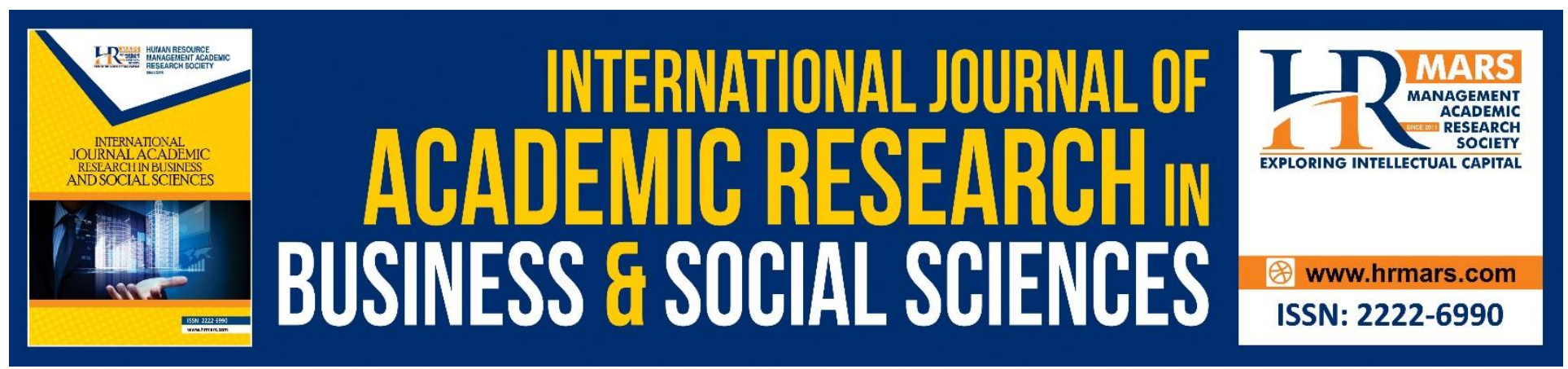

\title{
The Need to Interpret Legal Norms
}

\section{Gina Emilia Tache}

To Link this Article: http://dx.doi.org/10.6007/IJARBSS/v8-i12/5324

DOI: $10.6007 /$ IJARBSS/v8-i12/5324

Received: 07 Nov 2018, Revised: 21 Dec 2018, Accepted: 28 Dec 2018

Published Online: 04 Jan 2019

In-Text Citation: (Tache, 2018)

To Cite this Article: Tache, G. E. (2018). The Need to Interpret Legal Norms. International Journal of Academic Research in Business and Social Sciences, 8(12), 1797-1805.

\section{Copyright: @ 2018 The Author(s)}

Published by Human Resource Management Academic Research Society (www.hrmars.com)

This article is published under the Creative Commons Attribution (CC BY 4.0) license. Anyone may reproduce, distribute, translate and create derivative works of this article (for both commercial and non-commercial purposes), subject to full attribution to the original publication and authors. The full terms of this license may be seen at: $\underline{\text { http://creativecommons.org/licences/by/4.0/legalcode }}$

Vol. 8, No. 12, 2018, Pg. 1797 - 1805

Full Terms \& Conditions of access and use can be found at http://hrmars.com/index.php/pages/detail/publication-ethics 


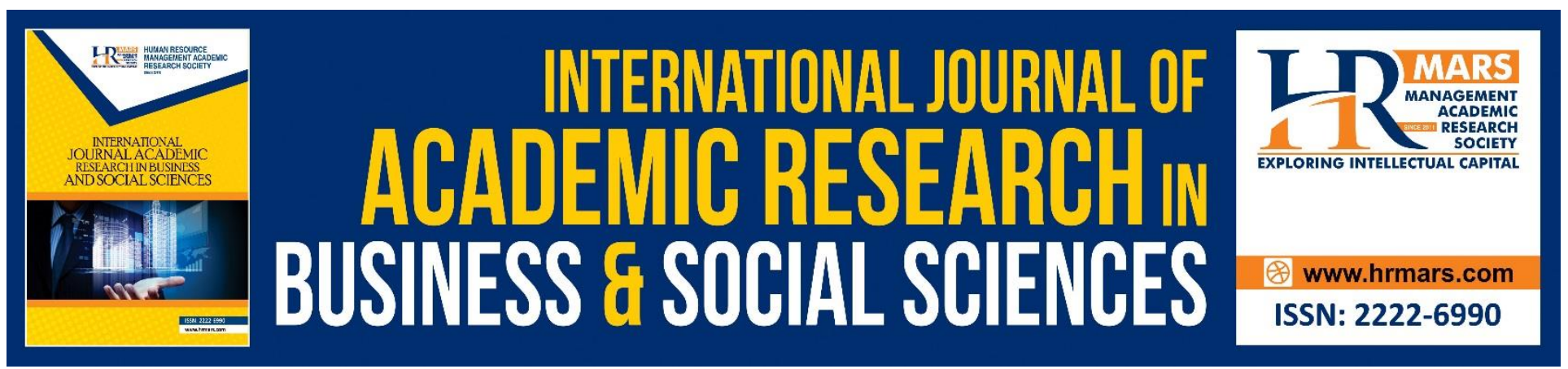

\title{
The Need to Interpret Legal Norms
}

\author{
Gina Emilia Tache \\ Juridical Researches Institute, Romanian Academy, Romania \\ Email: gina.tache@yahoo.com
}

\begin{abstract}
At present, there are numerous laws without the right conditions to be long analyzed and correlated. Therefore, many laws are not well-formulated, which sometimes confuses judges. Although the laws should be particularly clear, sometimes judges are not built on the meaning of the norms they are going to apply, only after deliberation and when they pronounce the solution in a particular cause. The legal norm is a general and mandatory rule of conduct whose purpose is to ensure the social order, the rule that can be enforced by the state and, if necessary, by coercion. All these factors that reveal the difficulty of breaking the meaning of the norm based on the words used by the legislator would appear to create so many obstacles to the uniform application of the legal norm. Therefore, it is necessary to overcome the apparent meaning of words and seek the deeper sense of the norm and its real scope of application.
\end{abstract}

Keywords: Legal Norms, Interpretation, Application, Words, The Rule

\section{Introduction}

As pointed out in the literature (Vida et al., 2016; Craiovan, 2015), knowing a rule of law is to find out what was the will of the legislator when drafting the law to allow the rule to be applied to the specific case, in the form and content that the legislator wanted to give it to him. Ideally, the legal norm should be so clear and precise that its simple reading is sufficient to establish the legislator's will expressed in the norm and at the same time make it clear and categorical that the rule applies to the specific case under discussion ${ }^{1}$ (Pena 2005). Unlike the situation, experience shows that this ideal can only be achieved, rarely. It follows that, however clear the rule of clarity should still be interpreted in order to determine whether it is applicable to the specific case (Popa, 2014).

\section{Content}

Starting from this finding, in the following lines, we want to take a closer look at the outstanding issues, both theoretical and practical. In this area, I have also shown that the legislator usually

\footnotetext{
${ }^{1}$ Claris non fit interpretation
} 
expresses his will in the norm using the words, which are not always sufficiently precise and faithfully to reflect the will of the legislator.

In addition, (Craiovan, 2007; Friedmann -Nicolescu, 2011) we would like to point out - in the same sense - that the legal norm is a generalization of the concrete situations that inspired the legislator; these abstract formulas cannot embrace the variety of cases that occurred in objective reality; therefore, the general wording, however well-conceived, will only partially and imperfectly embody the reality that the legislator (Dogaru et al., 2006), chose to regulate.

We add one thing that seems to us to be extremely important. We know that the rule of law is to apply to very vary concrete cases. Just as the abstract formula of the law has failed to fully encompass the reality that has inspired it, it will not even be able to embrace the variety of concrete cases that call for its application after the entry into force of the law (Craiovan 2007). Hence the need for a thorough clarification of the will expressed by the legislator in the legal norm and the scrupulous verification of whether this will also takes into account the concrete case to which the rule should apply.

We will add some observations at first glance, but it may not matter. For example, we note especially in the literature that if Beccaria in its time considered that there is no greater danger for legality than interpretation, later times have enshrined the idea that interpretation is always necessary (Popescu, 2011); even the seemingly clear rule may sometimes require an interpretive effort to be applied.

In addition, we underline the fact that, as the legal norms, preset in relation to the facts and the situations they regulate, are expressed in a general and impersonal form, their translation in fact requires their materialization in several aspects, as would be: in terms of the determination of natural or legal persons, bearing certain subjective rights or having certain legal obligations or being subject to some sanctions; from the point of view of the precise establishment of the rights and obligations deriving from the legal norms and sometimes the application of the sanctions as a result of the non-observance of the norms and the determination of the best means of achieving the legal norms, when this norm leaves the enforcement bodies freedom such a determination.

In relation to the previous developments, it has been fully explained in the legal science that the legal norms are accomplished in several forms, namely: by applying the legal norms by the state organs having this attribution within the legal limits of their competence; by bringing the legal norms to fulfillment by the citizens, this implementation has been shown in this way, either by the form of observance of legal norms, for example administrative rules, or by the way of enforcing the legal norms, using, in the prescribed manner, certain rights such concluding leases, sale, donation, etc.

In this context it is considered that the implementation of the legal norms, and in particular the application of these norms by the state bodies, requires the following operations to be carried out in advance: the exact determination of the factual situation for which the legal norm is to be settled, the detachment from this situation in fact, of legal features and the establishment of the conditions under which the legal rule in question applies; the determination of the legal rule governing the situation in question (for example, it has been shown that, in the last version in force, the text of the rule applicable in the present case was referred to as the lower critique, the verification of the legality of the rule as regards the competence of the body from which it emanates, an operation called the upper critique); the full understanding of the meaning, purpose and essence of the legal norm, determining the extent of the rule and its scope (Popa, 2014; Pașalega, 1960; Popescu et al., 2016). 
As has been shown, the last operation or more precisely this complex of rational operations is the interpretation of the rule of law (Dogaru et al., 2008; Pașalega, 1960). We also share this last point. the principal tenant's request to the housing service must be written and registered with this service ?; in the event that the same living space that has been allocated under the above conditions or another surface becomes available subsequently, the principal lessee is entitled to exercise his right of option again (loffe, 1960). From this analysis, it follows that this content, obtained as a result of the interpretation, is not an addition to the norm but only the disclosure of the real content of art. 16 and other rules, that make application of the text conditional (loffe, 1960).

It should not be forgotten, by way of example and par. 1 of art. 1266 par. (1) C.civ. in force. The text thus provides, "Contracts shall be interpreted according to the will of the parties, not the literal meaning of the terms. Mutatis mutandis, this rule of interpretation can also be used to illustrate the exact meaning of a text of the law. Indeed, such a text must be understood according to the real will but in this case the legislature and not the parties to the contract (Pătrașcu, 2012).

In this regard, we note, in the literature, the insistence on the idea that sometimes even strictly legal terms have different meanings (Pătrașcu, 2012). This idea is underlined by the author Bogdan Pătraşcu, scientific researcher gr. II at the Institute for Legal Research. He drew the attention that the sensing is usually defined as the possession of the right of the heresy of some of the heresies from the date of the inheritance. In this definition, the term possession has a particular meaning, distinct from what in general means possession, as a state of fact (Antoniu, 2006). We note that the author points out that both meanings are legal, and the distinction is thus necessary within the technical sense of the specific language. In this respect, in the legal doctrine, it has been shown that the language of a language (that is, the totality of words in a language) is not something given and unchangeable, but is constantly changing, language making efforts to adapt to changing realities. But even for a determined period, the meanings of a word may be different in relation to the degree of culture of different groups of citizens, their habits and their way of life (Friedmann-Nicolescu, 2011). Besides, the same specialist also points out that many laws currently exist without the right conditions to be long analyzed and correlated. Therefore, many laws are not well-formulated, which sometimes confuses judges. Although the laws should be particularly clear, sometimes judges are not built on the meaning of the norms they are going to apply, only after deliberation and when they pronounce the solution in a particular cause.

All these factors that reveal the difficulty of breaking the meaning of the norm based on the words used by the legislator would appear to create so many obstacles to the uniform application of the legal norm. Therefore, it is necessary to overcome the apparent meaning of words and seek the deeper sense of the norm and its real scope of application (Antolisei, 1994).

The examples given by both the authors of the general theory of law and the authors of civil law can be concluded that, with regard to the literal content appearing at first glance, the interpretation operation often brings something extra, whether these developmental ideas are an extension or a restriction of the scope or effectiveness of the legal norm (Manchester, 1998).

Next, we will recall that the interpretation of some legal terms gave rise to two different doctrinal opinions. According to one, the content of those terms must be inferred from the national law of the Contracting States. According to the second opinion, the European Court of Human Rights has to interpret the legal terms in an autonomous way. 
In explaining this latter view, the notion of "autonomy of the concepts of the Convention" has its own significance to the Court's normative system, and the concepts cannot be identified with homonymous concepts of different legal orders (van der Meersch, 1988).

These concepts are usually presented by the doctrine as concepts that the European Court of Human Rights removes from the national legal context in order to give them a "European" meaning, valid for all contracting states: proceeding to an "autonomous" reading of the European Convention of human rights, the European Court of Justice in Strasbourg ensures the indispensable uniformity of its interpretation and tends to avoid that European rules on the protection of human rights vary, such as the legal qualifications of national systems (Picheral et al., 2012).

The autonomous concepts established by the European Court of Human Rights thus allow a uniform definition of the commitments of the States and, at the same time, ensure the equal treatment of individuals and states for the main European instrument in the field of human rights (Picheral et al., 2012). From this, we note, in the literature, at least eight concepts have been formally "autonomous" by the Strasbourg European Court, namely "arrest", "civil rights and obligations", "criminal matters , "Witnesses", "accusation", "punishment", "public utility", "goods" (Picheral et al., 2012). This list was supplemented by legal doctrine with other notions: "family life" etc. In this regard, we should not forget the implications of judicial practice (Picheral et al., 2012). We remind you, in the Deweer v. Belgium judgment, that the Court defined the "accusation" as "the official notification by the competent judicial body of the accusation of have committed an offense which has significant repercussions on the suspect's situation, "and the criminal nature of an allegation depends on the nature of the offense and the degree of severity of the sanction (Picheral et al., 2012). As a consequence, it can be said that the legal norm must ultimately be applied uniformly, regardless of how to think and behave different categories of citizens, irrespective of the weight of expressing in words what the law orders or prohibits, so that citizens abstain from a certain behavior or adopt a certain behavior (Picheral et al., 2012).

We must also emphasize that interpretation is necessary in law enforcement in concrete cases (Pașalega, 1960). From this point of view, the doctrine shows that so harsh was the link that, from ancient times, the legislators have assumed the monopoly of interpretation, so that the law applies exactly as they have thought. It is enough to remember ancient Rome. From what has happened in the past, we notice that it was dominant that the once elaborated law applies identically throughout its duration and that the lawmaker is infallible, the law cannot contain any mistake; even if there were some blurring, only the legislator could interpret the law ${ }^{2}$ (Popa, 2014). Moreover, in the Roman Empire Justinian decided that only he can interpret the laws, forbidding any other interpretation and even commenting on the laws, starting from the fact that he is the exclusive creator and interpreter of law (Popa, 1997). However, it may be noted that Napoleon, having taken note of the commentary on the French Civil Code, would have spoken the words "Mon code est perdu" (Savigny, 1840; Popa, 2014)-My code is lost!. Hence, it follows that the thesis of those times was the prohibition of any interpretation of the law - apart from the authentic one, judges being compelled to respect the letter of the law and obey them, regardless of its possible imperfections. We exemplify, (Popa, 2014; Popa, 1994) "The sentences must be given so precisely that they should

\footnotetext{
${ }^{2}$ ejus est interpretari legem cujus est condere
} 
never represent anything other than the letter of the law. If they could express the judge's rigid views, we lived in society without knowing precisely what obligations I assumed for her "..." The judges of the nation ... are nothing more than the language that pronounces the theses of the law: that is, they are so deprived of their soul that they cannot attenuate their hardness or gentleness (Nedelschi, 1950) Montesquieu, About the Spirit. The same thesis we find in Beccaria. Thus, "... the judge, just as he is not a legislator, cannot be led to interpret criminal laws."

Subsequently, developments have demonstrated the impossibility of abandoning the interpretation of the law, given its inability to respond to all the needs of reality, facts far exceeding the content of the law, in the second half of the nineteenth century the school of "free law" 3 who militated for the full freedom of the judge to interpret the law, including beyond its explicit text. Even when they admitted some obligation to respect the text of the law of the time lawyer, they referred to the legislator's historical will from the time of the drafting of the law ${ }^{4}$ and the observance of the law content as conceived by such legislator. However, Freirechtslehre's doctrine of Freedom of Freedom was criticized because of the too great freedom it gives to the judge in the application of the law (Popescu et al., 2016).

Later, the conception of dynamic interpretation, which allowed the extension and adaptation of the law's content according to the real needs of society, emerged (Popa, 2014).

If within the static conception of interpretation it was considered that there is a complete concordance between the letter of the law and what the legislator thought to regulate, so that the letter of the law had to be absolutely respected (cult of the law), in the evolutionary conception of interpretation (Szabo, 2017) it is recognized that there may be a distinction between the letter of the law and its real meaning, meaning the legislator must identify beyond the law (Popa, 2014, Popescu, 2016). In other words, the evolutionist conception not only admits, but considers it absolutely necessary to develop the content of the law on the way of interpretation and correspondingly to the "purpose of the law - the teleological method", i.e. the modification of the law (Friedmann-Nicolescu, 2011). About static and evolutionary conception, see Luki Theory of Law, 3rd edition, 1958.

In another conception, it has been argued that there will always be a limitation when the affiliation or non-normality of a conduct is a questionable solution (Quintero Olivares et al 2000). This limit increases when we deal with vague elastic rules whose field of application is not well determined ${ }^{5}$ and is reduced in the case of rules with terminology precise (Hennau, 1995; Popa, 2014).

It should also be added that in foreign doctrine, as a rule, words cannot reflect the whole reality, and there is often a possible gap between language and reality (Antoniu 2006, Riteș 2014). In the same way, legal language is often unequivocal, ambiguous what makes interpretation necessary to choose in the semantic space the real sense of the rule of law,( Friedmann-Nicolescu, 2011; Riteș, 2014) meaning the sense closer to the will of the legislator. In this respect, it is argued that the legal framing of a concrete act obliges us to establish the correct meaning of the rule in order to be able to draw the conclusion whether or not the concrete features of the norm are present (Antoniu, 2016). In this way, the interpretation, starting from the norm, from the concrete case and from it to the norm, the

\footnotetext{
${ }^{3}$ In Germany and corresponding to it the scientific school in France

${ }^{4}$ Static conception of interpretation

${ }^{5}$ For example, the expression "public puffiness", public order, etc.
} 
result becomes a real mediation between the abstract norm and the concrete case (Antoniu, 2016). This perversion between the abstract norm and the concrete case is not a neutral, purely mechanical operation, the normative provision being often susceptible to a plurality of meanings, and influenced by a series of existing factors beyond the literal sense of the norm, namely the interpreter's personal views, its political, ideological conception, the concern about the type of impact that the decision could cause on the offender, the influence exercised on the social environment, etc. There is even talk of a jurisprudential law that tends to overcome the limits of the law, emphasizing the creative component of the performer's work (Pastor 1994). The need for interpretation is also justified by the fact that, in the application of the law, as stated above, the implementing body has to clarify the text of the legal rule with precision, to establish its compatibility with a certain factual situation, which is the case before him (Voicu et al., 2013). In connection with this, it has been shown that the legislator always has a system of norms of a general and impersonal nature, from which he has to choose the one that applies in the specific case - a particular and individual case determined by features that do not, and I always find accurate and detailed coverage of the content of the rule. In this respect, the enforcement body - interpreter - is obliged to identify the meaning of the rule of law, to verify the meaning of the words used by the legislator, whether he has thought or expressed correctly, whether he has made limitations, or has maintained the limits of a framework regulation, etc. Analysis of the text of the law raises the wider problem of meaning systems and the common language system (Riteș, 2014; Popa, 1999).

From the first point of view, the interpretation is to determine, in particular, the applicability of the provision of the rule to a particular person or certain persons, whether natural or legal, according to the territorial criterion, such as, for example, the domicile or the person's place of residence, etc. In the Romanian doctrine it has also been pointed out that interpretation of the legal norm is also necessary for the determination of the nature and the character of the legal norm. In this regard, we recall:

From a first point of view, it is important to establish and discuss often whether certain rules are imperative or device only. For example, we recall that the Supreme Court has disagreed with the nature of the provisions of the Labor Code in the sense that they are imperative and consequently the actions concerning relations governed by the Labor Code must be introduced within the time limits provided by this Code, and the party who lost the term in the Labor Code can no longer apply to the court of common law for the same claim, within the general limitation period stipulated in Decree no. 167/1958 (lonașcu, 1962).

In another study titled: German Legal Interests in Law, analyzed in Switzerland and Italy (I) - the author of Sofia Popescu, believes that Heck's merit of reconciling theory with practice has to be recognized on the mined field of autonomy judicial power, theory and fiction, in matters of court empowerment. They appreciate that the admission by Heck of the judge's ability to issue judgments of value, on the one hand, and the subsidiary nature of these assessments, on the other hand, bears the mark of moderate pragmatism, removing the conflict between the two powers in the extent to which the judge does not intervene with his own assessment system, except in the absence of an assessment made by the legislator, so only in the event of a gap. Not less, Swiss analysts regret that Heck did not give a more generous space to the issue of conflict between value judgments made by the legislator and judgments of value made by the judge (Hogaș et al., 1960). 
In addition, to the above-mentioned arguments, the teacher, and the high magistrate, Judge Nicolae Popa adds other reasons. For example, judicial practice, as a source of law, court solutions, judgments given on the basis of a certain interpretation, are not recognized, and are not binding on other courts when dealing with similar cases. Also, the judge is not obliged to give the same law the same interpretation he has given to a previous case (Popa, 2009).

In conclusion, when the legal rules are in force, new facts and situations are emerging, which were not directly or fully foreseen at the time of their elaboration. Subsequently, new legal rules come into force that directly or indirectly affect the scope of the existing rules or the rights and obligations contained therein.

\section{Conclusions}

All this requires that the meaning and content of a particular rule be clarified, depending on the specific case, to which rule is to be applied. Therefore, it must be stated, in principle, that any legal provision is amenable to interpretation and that no legal rule is exempt from the obligation to interpret it.

Lastly, it has also been argued that, during the practical application of a rule of law, interpretation or interpretation of the whole of the interpretation process, it is no longer outlining, it is no longer materialized in the law enforcement act, as the specialized and experienced enforcement body uses the results of its previous interpretations or interpretations by other bodies - in particular guidance decisions - or legal literature.

\section{Références}

Antolisei, F. (1994). Manuale di diritto penale, Parte generale, Ed. Milano.

Craiovan, I. (2007). Tratat de teorie generală a dreptului.

Craiovan, I. (2015). Tratat de teoria generală a dreptului, ediţia a III-a.

Dogaru, I., Dănişor, D.C., Dănişor, G. (2006). Teoria generală a dreptului - Editura C.H.Beck Bucureşti. Dogaru, I., Dănişor, D.C., Dănişor, G. (2008). Teoria generală a dreptului, Ed. C.H.Beck, Bucureşti.

Friedmann-Nicolescu, I. (2011). Abordări atipice ale interpretării normelor juridice din perspectiva culturii juridice, în Justiţie, stat de drept şi cultură juridică, Sesiunea anuală de comunicări ştiinţifice 13 mai 2011, Bucureşti.

Hennau, C., Verhaegen, J. (1995). Droit pénal général, Editions Bruylant, Bruxelles.

Ioffe, O. S. (1960). Drept civil, Editura Ştiinţifică, Bucureşti.

Matchester, F. (1998). Contraintes de l'intereptation de la Convention européenne des droits de I'homme, Bruxelles, Bruyant.

Pătraşcu, B. (2012). Interpretarea şi efectele legii civile, Noul cod civil, Studii şi comentarii, vol. I. Ed. Universul Juridic, Bucureşti.

Popa, N. (1994). Teoria generală a dreptului, Ed. Actami, Bucureşti.

Popa, N. (1996). Teoria generală a dreptului, Ed. Actami, Bucureşti.

Popa, N. (2009). Consideraţii generale privind conceptul de izvor al dreptului, în honorem, George Antoniu, Culegere de studii juridice, Ed. Sitech, Craiova.

Popa, N. (2013). Teoria generală a dreptului, Ed. C.H. Beck, Bucureşti.

Popa, N. (2014). Teoria generală a dreptului, ediţia 5, Editura C.H. Beck. 
Popa, N., Eremia, M.-C., Cristea, S. (2005). Teoria generală a dreptului, Editura All Beck, Bucureşti.

Popa, N. (coordinator), Anghel, E., Ene-Dinu, C., Spătaru-Negură, L. (2017). Teoria generală a dreptului, Caiet de seminar, ediţia 3, Ed. C.H.Beck.

Popescu, S. (2005). Statul de drept şi integrarea europeană, din perspectiva dreptului comparat, în Dreptul românesc şi Constituţia europeană, vol.III, Ed. Tempus.

Popescu, S. (2016). Teoria generală a dreptului Ştiinţa dreptului, in Jus est ars boni et aequi, Ed. Pro Universitaria.

Popescu, S., Hrestic, M.L., Serban, A., Stancu, R., Viziteu, M. (2016). Teoria generală a dreptului, Curs universitar, Ed. Pro Universitaria.

Riteş, L. (2014). Interpretarea. Instituţie fundamentală a dreptului, Ed.Universul Juridic.

Savigny, Fr. C. (1840). System des heutigen romischen Recht (Sistemul dreptului roman de azi) vol. I, Berlin.

Tamsin Pickeral (1997). „Cahiers de l'Institut de Droit Europeén des Droits de I'Homme", Université de Montpellier, Faculté de Droit et des Sciences economiques.

van der Meersch, W.J.G. (1988). Le caractère autonome des termes et la marge d'appreciation des gouvernements dans l'interpretation de la Convention européenne des droits de l'homme, „Melange en I'honneur de G. J. Wiarda", Koln, Heymann.

Vida, I., Vida, I.C. (2016). Teoria generală a dreptului, Curs universitar. 